\title{
Zirconium Zr 89-labeled Monoclonal Antibody MMOT0530A
}

National Cancer Institute

\section{Source}

National Cancer Institute. Zirconium Zr 89-labeled Monoclonal Antibody MMOT0530A. NCl Thesaurus. Code C106367.

A radioimmunoconjug ate composed of a monoclonal antibody that targets an antigen overexpressed in pancreatic and ovarian cancer and labeled with the radioisotope zirconium $\mathrm{Zr}$ 89, with potential use for assessing tumor antigen expression using positron emission tomography (PET). Upon administration of zirconium Zr 89-labeled monoclonal antibody MMOT 0530A, this agent targets an antigen expressed on certain tumor cells and is internalized. Following tumor cell uptake, the radioisotope moiety can be visualized using PET imaging. This may result in both the quantification of tumor antigen expression and an assessment of the response to treatment with therapeutics targeting the antigen. 